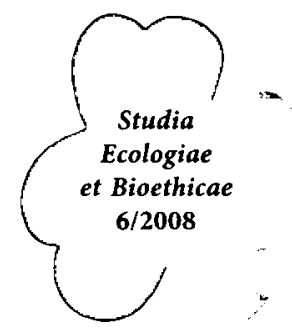

\title{
Wpływ działalności promocyjno-informacyjnej administracji państwowej i samorządowej na rozwój regionu na podstawie badań przeprowadzonych w gminie Orzysz
}

\section{Słowo wstępne}

Reforma samorządowa w Polsce miała na celu decentralizację władzy tak aby była ona "bliżej” społeczeństwa. Co to oznacza w praktyce? Władze samorządowe przejęły część kompetencji od urzędów centralnych dzięki czemu mogą one dostosowywać własną politykę regionalną do konkretnych potrzeb. Obowiązki które za tym idą dotyczą wszystkich dziedziń działalności społeczno-gospodarczej.

„Konstytucja stanowi, że podstawową jednostką samorządu terytorialnego jest gmina, która wykonuje wszystkie zadania samorządu niezależnie od innych jego jednostek. Jednostki te będą mogły być utworzone na podstawie ustawy jako jednostki samorządu regionalnego albo lokalnego i regionalnego." Przepisy ustaw o samorządach dokładnie regulują zakres kompetencji każdego z nich. "Gmina realizuje zadania publiczne o znaczeniu lokalnym. Są to zadania własne gminy m.in. prowadzenie spraw $z$ zakresu ladu przestrzennego, gospodarki terenami, gminnych dróg, ulic i mostów, wodociągów, zaopatrzenia w wodę, usuwania i oczyszczania ścieków komunalnych, pomocy społecznej, oświaty, kultury, targowisk i zieleni komunalnej, albo zadania zlecone $\mathrm{z}$ zakresu administracji rządowej. Zadania te zawarte są $\mathrm{w}$ ustawie o samorządzie terytorialnym. Jednakże dokładne ustalenie zadań własnych gminy i zadań zleconych regulują ustawy z dziedziny działalności społecznej i gospodarczej. Również inne ustawy np. o systemie oświaty, o zakładach opieki zdrowotnej, o opiece społecznej, o planowaniu przestrzennym ustalają, które zadania są zadaniami gminy, i które za nich mają charakter zadań własnych, a które są zadaniami zleconymi. Zadania własne są finansowane $\mathrm{z}$ dochodów gminy, np. podatków, opłat, wpływów $z$ majątku, a także $z$ subwencji ogólnej. Zadania zlecone są natomiast finansowane $\mathrm{z}$ dotacji celowych przekazywanych przez administrację rządową."

Z. BukowsKi, T. JĘDRzejewski, P. RąCZKa, Ustrój samorzq̨du terytorialnego, Stowarzyszenie Wyższej Użyteczności „Dom Organizatora”, Toruń 2003, s. 55.

2 A. Borodo, Samorzad terytorialny system prawno finansowy, Wydawnictwo prawnicze PWN, Warszawa 1997, s. 38-39. 


\section{Charakterystyka gminy i miasta Orzysz}

Współcześnie gminy polski Północno-Wschodniej stoją przed bardzo poważnym problemem, jak poprawić warunki społeczno-gospodarcze w tym regionie? Wzrost gospodarczy w naszym kraju niemal nie dotyczy obszaru kiedyś nazwanego „Polską B". Wysokie bezrobocie, brak infrastruktury drogowej i kolejowej, brak ośrodków przemysłowych sprawia, iż mimo sukcesów gospodarczych kraju w tej jego części ludziom żyje się biednie a warunków dla sprowadzenia inwestorów nie ma. Jedyną szansą dla tych regionów jest wykorzystanie ich walorów przyrodniczych. Jedną z takich gmin, która w ten sposób widzi swoją szansę na rozwój jest gmina Orzysz.

Gmina Orzysz położona jest w północno-wschodniej części województwa Warmińsko-Mazurskiego, w powiecie Piskim, na obszarze Pojezierza Mazurskiego. Teren ten wchodzi w skład Krainy Wielkich Jezior Mazurskich. Prawie połowa obszaru to lasy, a $10 \%$ obszaru to jeziora, których na terenie gminy znajduje się 21 oraz kilkanaście oczek wodnych. W bezpośrednim sąsiedztwie gminy Orzysz położone jest największe jezioro w Polsce - Śniardwy. Największym ośrodkiem miejskim regionu jest Orzysz, który położony jest pomiędzy Pojezierzem Ełckim, Pojezierzem Olsztyńskim i Pojezierzem Mrągowskim oraz Wysoczyzną Kolneńską. „Początek miasta - zwanego też niegdyś Orzeszem, Ariszem, Orseache, Rozyszem czy też Arysem - sięga pierwszej połowy XV wieku. Orzysz powstał ze wsi założonej przy starym szlaku handlowym, będącym jedynym przejściem wśród lasów, jezior i bagien. W XVII wieku wieś słynęła $\mathrm{z}$ targów lnem i płótnem lnianym. Wieś rozbudowując się wzdłuż drogi przybrała kształt ulicówki (typowy dla wsi czynszowych). Dzisiejszy układ przestrzenny miasta jest wyraźnym rozwinięciem tej pierwotnej formy osiedla wiejskiego. Ze względu na dogodne położenie na skrzyżowaniu szlaków komunikacyjnych szybko stała się ludną i dużą wsią. Odbywało się w niej wiele stałych jarmarków i targów. 1 marca 1725 roku Orzysz uzyskał prawa miejskie. Miasto otrzymało herb przedstawiający orła, trzymającego w szponach skrzyżowane berło, szpadę i róg obfitości. Rozwój miastu przyniosło ulokowanie tu w 1753 roku garnizonu wojskowego. Zdarzeniem które definitywnie wyprowadziło Orzysz z zastoju gospodarczego, było niewątpliwie założenie poligonu w 1890 roku. Powstał on na terenach zakupionych od wsi Wierzbiny i Szwejkówko oraz lasów Grądowskich i Drygalskich. Kryzys gospodarczy z pierwszej połowy XIX wieku odbił się bardzo niekorzystnie na Orzyszu, w latach sześćdziesiątych tego wieku był on miastem biednym, nieposiadającym żadnego majątku."3 Sytuacja zaczęła się polepszać pod koniec wieku, kiedy to miasto otrzymało połączenia drogowe, następnie kolejowe z Piszem, Giżyckiem, Mrągowem i Ełkiem. Największy wpływ na szybki rozwój miasto zawdzięcza rozbudowie poligonu wojskowego. Przed pierwszą wojną światową miasto było prężnie rozwijającym się ośrodkiem turystycznym. Najczęstszym celem wycieczek (odbywanych łodziami) w owym czasie, była duża wyspa na jeziorze Orzysz.

\footnotetext{
3 A. Stachurski, Orzysz i okolice, Agencja Fotograficzno-Wydawnicza „Mazury”, Olsztyn 2005, s. 10.
} 
Współcześnie miasto Orzysz ma powierzchnią $8,16 \mathrm{~km}^{2}$. Mieszkańców jest ok. 6300 osób. Gminy ma powierzchnię $363,49 \mathrm{~km}^{2}$ i ok. 10500 mieszkańców.

Najstarszym obietkem zabytkowym w mieście jest kościół ewangelicki z XVI wieku (obecnie kościół katolicki pod wezwaniem Matki Boskiej Szkaplerznej). Zabytkiem jest też kościół pod wezwaniem Najświętszego Serca Pana Jezusa z przełomu XIX i XX wieku oraz kilka domów z przełomu XVIII i XIX wieku. Bardzo dobrze zachował się także zabytkowy węzeł kolejowy z XIX wieku i należący do niego dworzec.

\section{Przyroda w gminie Orzysz}

Zachodnia część gminy to początek obszarów objętych Mazurskim Parkiem Krajobrazowym, w skład którego wchodzi jezioro Śniardwy wraz z terenami przybrzeżnymi. W obrębie gminy znajdują się też inne obszary chronione np.rezerwat Bagna Nietlickie, który stanowi część najlepiej zachowanego, największego torfowiska niskiego na Pojezierzu Mazurskim. W rezerwacie tym występuje wiele gatunków rzadkich roślin i zwierząt, jak np. brzoza niska, pełnik europejski, żurawie, czy błotniaki. Obszarem chronionym jest też torfowisko Rząśniki wraz z jeziorkiem Suchar oraz Wyspą Róż będącą strefą ochronną orła bielika i kani czarnej. Dużym atutem przyrodniczym miasta i okolic jest czyste powietrze nieskażone przemysłem, ogromne obszary leśne obejmujące ok $40 \%$ powierzchni gminy a także 20 jezior $z$ których największy obszar zajmuje Jezioro Śwniardwy.

Bardzo cenne przyrodniczo obszary stanowią kompleksy leśne, których udział powierzchniowy w gminie Orzysz to $40 \%$. W różnego typu lasach i borach na terenie gminy występuje wiele interesujących i rzadkich gatunków zwierząt jak wilki, jelenie, sarny, rysie, losie, żubry, a także ptaków np. bociany białe, perkozy dwuczube, kaczki krzyżówki, gąsiorek, trzcinak, kormorany.

\section{Gmina Orzysz - perspektywy rozwoju}

Brak ciężkiego przemysłu przez wiele lat był główną przyczyną rosnącego bezrobocia. Ukształtowany w powojennej Polsce rolniczy charakter tych terenów utrzymał się aż do dnia dzisiejszego, z tym, że Państwowe Gospodarstwa Rolne dawały pracę całym wsiom a w wyniku przekształceń po 1990 roku stopniowo były likwidowane. Wśród mieszkańców gminy są osoby, które od czasy zamknięcia PGR-ów nie podjęły pracy do chwili obecnej. Bardzo słabo rozwinięta infrastruktura komunikacyjna, gazownicza i kanalizacyjna dodatkowo obniża atrakcyjność inwestycyjną tego terenu. Niewiele osób zdaje sobie $\mathrm{z}$ tego sprawę, że dzięki temu udało się zachować ogromne tereny bardzo cenne przyrodniczo. Wykorzystanie tego aututu poprzez różne formy turystyki stanowi ogromną szansę dla ożywienia gospodarczego w gminie Orzysz.

Dziesiejsza turystyka nie może istnieć bez sprawnej promocji. Jest to klucz do sukcesu. Wszelkie działania promujące region jako czysty ekologicznie a przez to atrakcyjny turystycznie powinne być poprzedzone badaniami, które wykażą mocne 
i słabe strony, co ułatwi planowanie działań. W tym celu została przeprowadzona analiza SWAT, która wykazała że mocnymi stronami gminy są:

- atrakcyjne położenie wśród jezior i lasów

- bogactwo fauny i flory

- bardzo dobry ogólny stan środowiska naturalnego

- brak zanieczyszczen przemysłowych

- liczne szlaki turystyczne

- szybko rozwijające sie zaplecze dla agroturystyki

Analiza wykazała również liczne słabe strony:

- brak infrastruktury drogowej, energetycznej i kanalizacyjnej

- niska ogólna aktywność gospodarcza mieszkańców

- bardzo wysokie bezrobocie

- niski udział kapitału spoza gminy na rzecz regionu

- bardzo niski dochód przypadajacy na jednego mieszkańca

Umiejętne prowadzenie kampanii promocyjnej stwarza szanse na poprawienie warunków społeczno-gospodarczych w regionie. Dzięki temu możliwe będzie rozwiązanie najważniejszych problemów gminy, przede wszystkim zaowocuje rozwojem turystyki dzięki której powstaną nowe miejsca pracy. Następstwem tego będzię rozbudowanie i moderniacja infrastruktury drogowej, energetycznej i kanalizacyjnej a co w dalszej perspektywie może oznaczać wzrost atrakcyjności tych terenów dla zagranicznych inwestorów.

Warto pamiętać, że Polska jako członek Unii Europejskiej może liczyć na wsparcie finansowe tej instytucji, która od lat wspiera inicjatywy lokalne. Dodatkowe fundusze znacznie przyspieszą realizację planów ożywienia gospodarczego gminy.

Analiza SWAT wykazała zagrożenia jakie się mogą pojawić w trakcie wdrażania planów gospodarczych gminy Orzysz. Najważniejszymi są, nieprzychylne decyzje Agencji Mienia Wojskowego oraz Agencji Własności Rolnej Skarbu Państwa, które to posiadają na terenie gminy znaczne obszary a na ich decyzje władze samorządowe nie mają rzadnego wpływu. Kolejnym zagrożeniem jest niekontrolowana ingerencja człowieka w środowisko naturalne co może skutkować jego degradacją czyli zniszczeniem głównego atutu gminy w walce o rozwój turystyki.

Gmina Orzysz to kraina malowniczych jezior i bujnych lasów. Wyjątkowe walory przyrodnicze oraz specyficzny mikroklimat tego regionu tworzą idealne warunki do zamieszkania, rekreacji i uprawiania turystyki. O atrakcyjności turystycznej gminy decydują przede wszystkim: nieskażone środowisko naturalne, bogactwo i różnorodność lasów oraz bardzo czyste akweny wodne. Sezon turystyczny w gminie trwa od długiego weekendu majowego do końca września.

Rozwój każdej gałęzi gospodarki musi odbywać się ściśle z zasadami racjonalnego wykorzystywania posiadanych dóbr, potencjału ludzkiego oraz możliwości rynkowych. Podobnie sprawa wyglada $z$ turystyką, $z$ tym, że posiadanym dobrem jest środowisko naturalne a możliwości rozwoju są ściśle powiązane z jego utrzy- 
maniem we własciwym stanie oraz profilaktyką ekologiczną, czyli edukacją proekologiczną. Rozwój ten powinien obejmować następujące dziedziny: poprawę infrastruktury drogowej, kanalizacyjnej i energetycznej, rozbudowę i modernizację bazy turystycznej, kształcenie kadr turystycznych oraz stworzenie systemu informacji i promocji oferty usług turystycznych.

Gmina Orzysz w celu wykorzystania turystyki jako głównego narzędzia dla poprawy sytuacji społeczno-gospodarczej na swoim terytorium musi przeprowadzic szereg inwestycji. Jedną z najważniejszych jest, włączenie gminy Orzysz do żeglarskiego szlaku turystycznego oraz przedlużenie sezonu turystycznego.

W związku z tym zaproponowano następujące zadania:

- udrożnienie Kanału Orzysz oraz budowa kanału łączącego jez. Tyrkło z jez. Bawełno (inwestycja kosztowna ale jej brak uniemożliwia rozwój turystyki wodnej),

- budowę nowych i modernizowanie istniejacych przystani żeglarskich i kajakowych na terenie gminy Orzysz,

- podnoszenie standardu i wyposażenia istniejącej bazy sportowo-turystycznej

- wytyczenie i oznakowanie szlaków turystycznych (rowerowych, pieszych, wodnych),

- modernizację i budowę urządzeń obsługi turystyki kwalifikowanej i krajoznawczej (pieszej, motorowej, rowerowej, wodnej itp.) - sanitariaty, serwis, itp.

- budowę ciągu pieszo-rowerowego z miejscami rekreacyjnymi wzdłuż Kanału Orzysz,

- kształcenie kadr obsługi turystycznej,

- stworzenie systemu informacji i promocji oferty usług rekreacyjno-turystycznych,

- organizację cyklicznych imprez promujących gminę np. regat żeglarskich, spływów, konkursów kulinarnych, festynów, itp.

- tworzenie wiosek turystycznych - wsie skupiajace gospodarstwa groturystyczne i pensjonaty,

- budowę plaż wiejskich, zagospodarowanie terenu przy Plaży Miejskiej w Orzyszu,

- systematyczne zarybianie jezior.

Wszelkie plany rozwoju gminy musza uwzględniać dotychczasowy jej charakter, czyli gminy typowo rolniczej. Założenia polityki w dziedzinie rolnictwa są bezpośrednio związane z ochroną środowiska naturalnego. Przewiduje ona działania zapobiegawcze polegające na neutralizacji zanieczyszczeń, ograniczeniu emisji substancji trujących oraz renaturalizację środowiska naturalnego. Głównym celem w tej kwestii jest podniesienie standardu życia i pracy na wsi poprzez podniesienie atrakcyjności turystycznej terenu. Jak uzyskać taki efekt? Powinno się zrealizować następujące zadania:

- stworzenie centrów wsi poprzez remont lub budowę dróg, chodników i oświetlenia,

- stworzenie miejsc wypoczynku, w tym urządzenie parków oraz plaż wiejskich, 
- popieranie drobnej wytwórczości na wsi - przekładem mogą być wyroby rzemieślnicze, które cieszą się dużą popularnością w znanych miejscach odpoczynku,

- konserwacja istniejących i budowa nowych urządzeń melioracyjnych dostosowanych do potrzeb poszczególnych ekosystemów,

- tworzenie gospodarstw ekologicznych $i$ ich promocja poza gminą - niezbędne jest przygotowanie folderów, informatorów oraz albumów które byłyby dostepne w całym kraju,

- powstanie nowych i rozwój istniejących gospodarstw agroturystycznych,

- wspieranie powstania grup producenckich np. regionalnych produktów mlecznych lub zbożowych,

- wdrażanie programów rolno środowiskowych,

- budowa elementów małej infrastruktury turystycznej oraz rekreacyjnej (pomostów i mol, tarasów widokowych, instalacji tablic dydaktycznych i informacyjnych związanych z oznakowaniem terenów atrakcyjnych turystycznie),

- zagospodarowanie i oczyszczenie zbiorników i cieków wodnych (udrożnienie szlaków kajakowych).

Gmina Orzysz ma bardzo duże możliwości rozwoju swojego środowiska przyrodniczego w połączeniu z jego wykorzystaniem dla celów turystycznych. Występujące na tym terenie duże kompleksy leśne o bardzo zróżnicowanej strukturze a także różnego rodzaju bagna, torfowiska i duże połacie łąk są ostoją dla ptaków i zwierząt. Region ten jest również bardzo cenny ze względu na dużą różnorodność gatunkow ptaków. Duże walory ornitologiczne podkreślane są przez wyznaczenie na jej obszarze ostoi ptaków o znaczeniu międzynarodowym, a mianowicie Puszcza Piska, Ostoja Poligon Orzysz oraz Bagna Nietlickie. Wszystkie te atuty warto wykorzystać w promocji gminy, zanim jednak to się stanie należy zająć się szerokopojętą poprawą stanu środowiska naturalnego. W tej kwestii głównym celem jest zmniejszenie poziomu zanieczyszczeń, w pojęciu tym zawiera się rozbudowa sieci kanalizacyjnych i wodociągowych. Gospodarka wodno-sciekowa jest głównym problemem gminy, brak uporządkowania tej kwestii jest najwiekszym zagrożeniem dla srodowiska naturalnego oraz czynnikiem zniechęcającym potencjalnych turystów. Kolejnym równie istotnym problemem są dzikie wysypiska smieci, które są prawdziwa plagą w gminie Orzysz. Nie można w akcji promocyjnej przedstawiać wizerunku gminy jako czystej i zdrowej a w rzeczywistości jest ona zaśmiecona. Konieczne są również akcje edukacyjne dla mieszkańców by uświadomić ich, że wszelkie działania mające zły wpływ na środowisko naturalne będą skutkowały pogorszeniem się ich stanu majatkowego, bo turyści przestaną odwiedzać te tereny.

Działalność promocyjna samorządu może wykorzystywać wszelkie dostępne środki przekazu. Do podstawowych należą: katalog informacyjny, ulotka reklamowa, informator regionalny, prasa regionalna. Oryginalnym sposobem promocji regionu jest wydanie albumu fotograficznego ukazującego najpiękniejsze zakątki gminy. Wydawnictwo takie pomimo tego, że jest stosunkowo drogie, cieszy sie dużym zainteresowaniem szczególnie u Niemców, licznie odwiedzających tereny dawnych Prus Wschodnich. 
Inną formą promocji jest stworzenie własnego portalu informacyjnego oraz wykupywanie bannerów reklamowych na portalach komercyjnych. Ta forma promocji dociera do szerokiej rzeszy internautów i z powodzeniem jest stosowana od lat przez najwiekszych hotelarzy i restauratorów w Polsce i na świecie.

Znakomitą promocją dla miasta jest ubieganie się o organizację dużej imprezy masowej. Przykładem może być pobliski Ełk, w którym zorganizowano imprezę promocyjną komercyjnego radia. Koncert wg. szacunków Policji przyciągnął na jeden dzień ponad 30 tysięcy ludzi.

Imprezę plenerową na wzór Uroczyska w Supraślu można organizować na rozpoczęcie i zakończenie sezonu. Ta forma promocji szczególnie sprawdza się w przedstawieniu walorów twórczości ludowej, tradycyjnej kuchni oraz ekologicznego rolnictwa. Towarzyszyć jej mogą prezentacje atrakcji przygotowanych dla turystów przez gospodarstwa agroturystyczne.

Szczególnie piękne krajobrazy sprzyjają organizacji różnego rodzaju rajdów. W calej Polsce znany jest spływ rzeką Krutynią, więc dlaczego nie wykorzystać doświadczeń mieszkańców tamtych terenów do promocji własnego regionu.

Realizacja planów rozbudowy i modernizacji infrastruktury dorgowej, energetycznej i kanalizacyjnej rownież może być wykorzystana w działaniach promocyjnych. Należy pamiętać, że najskuteczniejszą formą reklamy jest tzw. „poczta pantoflowa" - zadowolony ze standardu usług turysta zarekomenduje wypoczynek $w$ tym miejscu kolejnej osobie.

\section{Zakończenie}

Nowoczesna turystyka nie może istnieć bez promocji. Gminy, które w turystach upatrują swoją metodę na poprawienie sytuacji społeczo-gospodarskiej na jej terenie muszą zdawać sobie sprawę, że działania promocyjne muszą być z góry zaplanowane bo klient niezadowolony $z$ usług którymi go zwabiono to klient stracony na zawsze a swoje złe doświadczenia przekaże innym ludziom.

Gminy na których terenie nie ma dużych zakładów przemysłowych a rolnictwo $z$ różnych przyczyn nie jest dochodowe starają się za wszelką cenę zwrócić na siebie uwagę potencjalnych inwestorów. Na terenach sąsiadujących $z$ wielkimi ośrodkami przemysłowymi wystarczy wystawić atrakcyjną ofertę na grunty i inwestor sam się znajdzie a o dojazd czy energię dla przyszłej inwestycji nie musi sie martwić. Polska Pn-Wsch jest pozbawiona takiej możliwości ze wzgledu na bardzo ubogą infrastrukturę drogową i energetyczną. Jedyną szansą rozwoju gmin jest wykorzystanie ich walorów środowiskowych.

Ochrona środowiska jest znakomitym pomysłem na promocję regionu bo w świadomości wspólczesnych społeczeństw wytworzył się etos, który mówi, że wszystko, co ekologiczne to dobre. Warto to wykorzystać. 